\title{
Índices de poesia em lavoura arcaica: da literatura ao cinema
}

\section{Poetic indexes in lavoura arcaica: from literature to cinema}

\section{Índices de poesía en lavoura arcaica: de la literatura al cine}

(iD) Francisco Heitor Pimenta Patrício

Universidade Regional do Cariri (URCA), Missão Velha, Ceará, Brasil.

E-mail:heitor2014@hotmail.com

iD Ana Carolina Negrão Berlini de Andrade

Universidade Regional do Cariri (URCA), Missão Velha, Ceará, Brasil.

E-mail: nba.anacarolina@gmail.com

Resumo: O presente artigo pretende fazer uma análise semiótica do livro Lavoura Arcaica (1975) de Raduan Nassar e do filme homônimo de Luiz Fernando Carvalho (2001). O objetivo deste trabalho é reconhecer as marcas de poeticidade que estruturam livro e filme, as quais dão origem a uma relação de homologia estrutural entre as obras. Igualmente, tem-se por objetivo explorar o efeito sinestésico provocado pelos elementos poéticos nas obras, buscando entender como o estímulo sensorial presente na obra literária e no filme resulta na corporificação máxima desses sentidos, adquirindo caráter sexual. Para confirmar tal hipótese nossa análise das obras será pautada pelas propostas de Pasolini (1966, 2000), Saverini (2004), Andrade (2010), Paz (1982) e Bosi (1977).

Palavras-chave: Lavoura Arcaica. Raduan Nassar. Luiz Fernando CarvaIho. Prosa Poética. Cinema de Poesia.

Abstract: The present paper intends to do an inter-semiotic analysis of Raduan Nassar's novel Lavoura Arcaica (1975), and the homonymous 
movie made by Luiz Fernando Carvalho (2001). This work objective is to detect the poeticity marks that structure both movie and book. At the same time, the paper explores the synesthetic effect created by the poetic elements in both works. It does so to understand how the sensorial stimuli present in both text and film results in the maximum embodiment of these senses, which acquires a sexual feature. To confirm this hypothesis, the writers did bibliographical research. The analysis was guided by the following theories: Pasolini (1966), Saverini (2004), Andrade (2010), Paz (1982) e Bosi (1977).

Keywords: Lavoura Arcaica. Raduan Nassar. Luiz Fernando Carvalho. Poetic Prose. Cinema of Poetry.

Resumen: El presente trabajo pretende hacer un análisis inter-semiótica entre el libro Lavoura Arcaica (1975) de Raduan Nassar y la película homónima de Luiz Fernando Carvalho (2001). El objetivo del texto es reconocer las huellas de poesía que estructuran libro y película. De la misma manera, hayel objetivo de explorar el efecto sinestésico provocado por los elementos poéticos en las obras, buscando comprender como el estímulo sensorial existente en el texto y en la película resulta en la corporeización máxima de eses sentidos, adquiriendo carácter sexual. Para asegurar tal hipótesis, realizamos una investigación bibliográfica. El análisis se hizo según las propuestas de Pasolini (1966), Saverini (2004), Andrade (2010), Paz (1982) y Bosi (1977).

Palabras-clave: Lavoura Arcaica. Raduan Nassar. Luiz Fernando Carvalho. Prosa Poética. Cine de poesia.

Submetido em 16 de julho de 2020. Aceito em 04 de setembro de 2020.

Publicado em 17 de maio de 2021. 


\section{Introdução}

Desde o nascimento do cinema, a sua proximidade com a literatura tem trazido discussões calorosas envolvendo o diálogo entre as duas formas de arte. Questões como a presença do narrador e como este se comporta, uma suposta pureza das duas artes e os procedimentos utilizados para a adaptação levam a questão a um constante debate. Por muito tempo, no período em que o cinema ainda tentava se estabelecer como arte autônoma, muitas comparações foram feitas em relação à literatura. Essas comparações acabaram por criar uma ideia de que o cinema era submisso à literatura ou, pior ainda, que o cinema necessitava da literatura e de suas técnicas para construir narrativas ou mesmo se estruturar, de maneira geral.

Precisamos entender, entretanto, que é compreensível que o cinema herde ou adapte algumas das técnicas da literatura, já que esta é uma arte narrativa mais antiga, assim como o teatro. Por outro lado, também é válido ressaltar que o inverso acontece, isto é, a literatura também busca no cinema novas técnicas de construção estética. Em vista disso, ao analisar o livro Lavoura Arcaica (1975), de Raduan Nassar, e o filme homônimo de Luiz Fernando Carvalho (2001), partimos do pressuposto não de encontrar exatidão e igualdade na adaptação, mas de atentar para as possíveis similaridades entre as obras. No caso da presente análise, a obra literária e sua adaptação/transcriação fílmica serão analisadas a partir das semelhanças estruturais, construídas a partir do conceito de poesia. Ou seja, pretendemos analisar as relações de homologia estrutural mantidas entre as obras. Assim, o nosso objetivo se pauta na análise dos procedimentos poéticos encontrados nas duas versões de Lavoura Arcaica. Segundo nossa hipótese, estes elementos poéticos constroem uma relação sinestésica, que resulta em uma corporificação máxima dos sentidos, devido ao caráter sexual que eles adquirem. 
Ìndices de poesia em lavoura arcaica: da literatura ao cinema

Francisco Heitor Pimenta Patrício • Ana Carolina Negrão Berlini de Andrade

Para confirmar tal hipótese, utilizaremos as propostas do artista italiano Pasolini (1966; 2000), que desenvolveu a ideia de um cinema de poesia e, mais que isso, de uma gramática própria ao cinema. Saverini (2004) e Andrade (2010) serviram como suporte para os estudos sobre o artista acima citado. Ainda como aporte teórico, utilizaremos Paz (1982) e Bosi (1977) para guiar nossa discussão a respeito da poesia e suas implicações, de modo a compreender as marcas da poesia na prosa.

\section{Cinema \& Literatura: diálogo e interação}

Sabemos que, ao compararmos literatura e cinema, é necessário entender que existe entre as duas uma grande diferença, já que ambas se expressam por meio de sistemas semióticos diferentes. É impensável para o cinema construir a mímesis do mesmo modo como esta é produzida na literatura, visto que, enquanto no cinema as imagens são o ponto de partida, na literatura elas são o resultado (SARAIVA, 2003, p. 26).

Entretanto, podemos analisar como esses dois meios de expressão podem se aproximar ao suscitar uma equivalência entre os sentidos sugeridos no livro e os que são sugeridos no filme, como também podemos analisar os procedimentos dos quais ambos se utilizam na construção estética e formal das obras, como o ritmo com que a história é contada, o discurso indireto livre, a montagem, ${ }^{1}$ entre outros procedimentos, que, se não são iguais devido à diferença de meio semiótico, podem ser aproximados a partir do conceito de homologia estrutural.

Assim como a literatura, o cinema desenvolveu um sistema de procedimentos que, pela convencionalidade de seu uso, remetem a significados específicos. Um exemplo disso são as técnicas usadas pelas produções cinematográficas de Hollywood, como o uso do zoom ou o plano detalhe, que geralmente representam foco

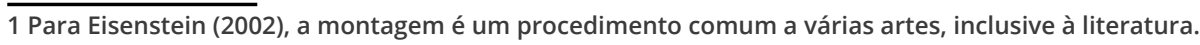


Ìndices de poesia em lavoura arcaica: da literatura ao cinema

ou atenção tanto por parte do personagem quanto para o espectador.

Essas técnicas visam construir uma estética e uma narrativa realistas e, na medida em que a câmera é tornada "invisível" por elas, temos a impressão que apreendemos as imagens do cinema do mesmo modo como apreendemos a própria realidade. No entanto, os procedimentos que buscam esse efeito de realidade são, na verdade, convencionalizações de técnicas já tão exploradas que não chamam mais a atenção do espectador, suscitando esse efeito de naturalidade. São justamente essas técnicas e signos visuais já naturalizados que formam a gramática do cinema sobre a qual falaremos a seguir.

No cinema, a gramática cinematográfica (PASOLINI, 2000) pretende ser realista, ou seja, a relação entre signo e significado deve parecer "transparente", a fim de simular a percepção da realidade objetiva. O problema é que o "realismo" também passa por um processo de convencionalização, de modo que sua representação muda com o tempo.

Essa questão nos leva a pensar no movimento contrário a este, que visa a percepção, por parte do espectador, das técnicas usadas na produção fílmica e na contrariedade a todo sistema já condicionado de referenciais imagéticos. Como foi sugerido acima, o cinema convencional busca aproximação máxima entre o filme e a realidade. O cinema de poesia, pelo contrário, é metalinguístico, já que enfatiza os próprios procedimentos e técnicas de construção do filme (PASOLINI, 1966, 2000).

O objetivo do diretor, para Pasolini (1966, 2000), é subverter as regras, as convenções, as técnicas de mimesis, isto é, proporcionar ao espectador uma visão que vai além da percepção da realidade objetiva. Ou seja, tudo no cinema de poesia converge no afastar-se da realidade e se aproximar do onírico, daí a montagem deslocada, isto é, o processo de pós-produção que busca subverter as regras estabelecidas buscando o onírico, como os enquadramentos não convencionais e a metaforização dos signos. Esse processo de 
metaforização ocorre, no cinema, quando os signos ultrapassam a própria realidade sensível e objetiva, para obter outros significados, que não a realidade imediata. Situação análoga pode ser atribuída à poeticidade literária, na qual predomina a linguagem figurada em detrimento da literal. Ou seja, a poeticidade na literatura também marca-se por um "desvio" do sentido unívoco da prosa em direção a uma plurisignificação, da qual a imagem poética e a metáfora são excelentes exemplos.

No cinema de poesia, essas técnicas tornam a obra muito mais autoral, permitindo uma expressão livre da estética do diretor, por meio da iluminação, do espaço, das cores, enfim, todos os procedimentos de realização do filme. Ou seja, por ter como objetivo criar significados utilizando não obrigatoriamente os procedimentos já consagrados, o diretor pode criar seus próprios métodos de construção do filme. Assim, além de possibilitar a produção e exploração de "possibilidades expressivas e a qualidade onírica intrínseca no cinema, em contraposição a toda a tradição narrativa 'tendencialmente naturalista e objetiva'"' (SAVERINI, 2004, p. 42), o cinema de poesia permite uma maior exploração no processo de confecção do filme em relação ao cinema comercial, "limitado" pelas convenções cinematográficas.

Quando analisamos essas questões, entramos em um universo de possibilidades quanto às técnicas desenvolvidas pelo cinema para se relacionar com a literatura, já que literatura e cinema não se aproximam apenas pela presença da narrativa. Bazin (1987 apud BRITO, 2006), por exemplo, afirma que a fidelidade entre a obra a ser adaptada e a adaptação, no caso da literatura e do cinema, é ilusória e não deveria nem ser almejada. Para o autor, a adaptação deve se comprometer em promover um novo conceito da obra que será objeto de adaptação. Por ser realizada por pessoas diferentes, em contextos político-sociais diferentes, a adaptação passa por processos de significação divergentes, de modo que os processos de construção simbólica pelos quais as obras vão passar serão, logicamente, distintos. 
Dessa forma, ao compararmos duas obras - literária e fílmica - nos deparamos com universos significativos diferentes, que podem se aproximar e se referenciar por meio não apenas da semeIhança dos aspectos temáticos, mas pelo resultado final da obra como um todo.

Nesse sentido, Cunha (2007), retomando o conceito de "tradução criativa" de Haroldo de Campos, defende que a re-elaboração audivisual "[...] para construção de uma nova narrativa, lança mão de texto marcado pela literariedade" (CUNHA, 2007, p. 13). Ou seja, os próprios procedimentos técnico-estilísticos da obra literária também são o foco de interesse na adaptação, de modo que a transcriação fílmica se preocupa com soluções técnicas e estilísticas que dialoguem com os utilizados na literatura. As formas de construção do filme em relação ao livro, a escolha das cores, da câmera, da montagem, todos esses fatores são suscitados no momento da adaptação e podem ser comparados com procedimentos literários. Um dos pontos de aproximação entre duas obras de sistemas semióticos diferentes pode ser a presença da poeticidade, como é o caso das obras aqui estudadas. O problema desse fato é que, para definirmos poesia, passamos por um processo de entender, segundo Paz (1982), que o termo poesia não tem uma definição absoluta. Quando nos referimos à poesia, não estamos falando de poemas ou características de períodos literários, estamos nos referindo a características que podem ser encontradas nos mais diferenciados meios artísticos e que podem dialogar, entre si, a partir dos elementos considerados poéticos, por exemplo, o tipo de linguagem usada, o ritmo da escrita, ou as imagens que são produzidas.

Na verdade, o autor afirma que tudo é poético (PAZ, 1982), desde pessoas, imagens, músicas, paisagens, até textos em prosa, ou tudo pode ser poético, já que a poesia, como foi dito, não está presa a formas literárias. Essa afirmação é complexa, já que, se não podemos definir o que é poesia, precisamos de características comuns, traços e similaridades entre pinturas, textos, músicas, paisagens etc., para que possamos, a partir destas, identificar o 
que é poético. Um critério para definirmos o que entendemos por poeticidade pode ser a questão da intencionalidade, já que, para Paz (1982), há uma diferença entre o que é naturalmente poético e a poesia que é construída conscientemente por alguém. Dessa forma, entendemos, como o autor, que é possível encontrar poesia em obras que passaram por um processo de criação formal elaborado com rigor, como no caso das obras em questão.

A nossa concepção de poético também é orientada pelas definições de Pasolini (1966; 2000) e Bosi (1977), os quais, como Paz (1982), afirmam que a poesia explora ao máximo a sensorialidade, simulando sensações por meio de seus procedimentos técnico-estilísticos, caso das metáforas, abundantes em ambas as obras. Justamente por conta da exploração acentuada desses procedimentos, Jakobson (2010) e Pasolini (1966; 2000) acreditam que a metalinguagem é característica inerente à poeticidade, uma vez que os procedimentos chamam atenção para si mesmos, isto é, para a própria construção estética das obras.

Ainda segundo Paz (1982), as características da poesia estão relacionadas às escolhas do autor em relação à linguagem, às imagens metafóricas que são produzidas por suas escolhas, ao ritmo que essas características desenvolvem e qual a relação com a significação total da obra. Essas características estão relacionadas diretamente com a forma, parte do plano da expressão, para dar vazão, ou melhor, aumentar a expressividade do plano do conteúdo. Sendo assim, é no plano estético, estrutural e formal que age a poesia.

Dessa feita, uma pintura e um livro, por exemplo, podem estar mais próximos por conta da homologia estrutural e por produzirem efeitos estéticos semelhantes do que dois livros, que possuem o mesmo sistema semiótico. No caso de um filme, por exemplo, se o seu processo de produção é feito com intencionalidade de ser poético, este pode suscitar o mesmo universo significativo de um livro. 


\section{A poesia como elemento estruturante em Lavoura Arcaica}

No caso da análise que propomos realizar, Lavoura Arcaica, filme e livro, o processo de criação é elaborado com base na presença da poeticidade em ambas as obras. Assim, o sentido final do livro e toda a sua construção é baseada na presença do poético. Dessa forma, a construção do filme se pautou em representar poeticamente os elementos também poéticos do livro, fazendo com que ambas as obras se aproximem sem perderem as características próprias a cada sistema semiótico. A presença da poesia no filme e no livro, portanto, é o elemento norteador para a adaptação e age como mediador entre os sistemas semióticos nesta análise.

A poesia também é tida como elemento estético que irá aproximar o sentido final das duas obras, já que, segundo a nossa leitura, esse sentido final da obra será a corporificação máxima dos sentidos que resulta no "tom" sexual que a obra traz. Essa corporificação é resultado do uso de procedimentos técnico-estilísticos que, como já mencionamos acima, exploram simultaneamente sensações sinestésicas e chamam atenção para si próprios, em processos altamente estésicos. Assim, se por um lado esses procedimentos representam e simulam sensações, as quais, segundo a nossa leitura, culminam em um tom sexual, por outro lado, a tessitura literária torna-se elemento sedutor e fonte de prazer estético.

A paleta de cores usada no filme é um exemplo da relação acima citada. Isso porque a paleta, composta de tons naturais, é predominantemente quente. Comumente, as cores quentes são usadas para dar a impressão de calor, de luz, de vida, e de intensidade. A história, no livro e no filme, é contada a partir da psicologia do personagem André, e as imagens produzidas pelo filme nos apresentam a forma como o personagem apreende a realidade. Assim, as cores sugerem uma intensidade exacerbada do personagem quanto ao lugar onde mora ou às pessoas que o rodeiam. 
Nesse sentido, é importante ressaltar que, para Pasolini (1966), uma das marcas de poeticidade do cinema é o uso da subjetiva livre indireta. Esta caracteriza-se como um "monólogo interior" desprovido de abstração, no qual a câmera, ao acompanhar a subjetividade e a psicologia de um personagem, se torna livre para "experimentar" esteticamente, dando vazão, portanto, ao estilo do realizador do filme. Segundo o cineasta italiano, "[...] a possibilidade de uma prosa de arte, de uma série de páginas líricas cuja subjetividade é assegurada pelo uso pretextual da subjetiva livre indireta e cujo verdadeiro protagonista é o estilo" (PASOLINI, p. 286, 1966). Desse modo, a presença da subjetividade do protagonista André, norteando os procedimentos fílmicos utilizados, é uma das características do cinema de poesia, como veremos abaixo.

Em ambas as obras, literária e fílmica, a história tem início com o encontro dos dois irmãos, André, que fugiu de casa, e Pedro, que estava à sua procura. Nesse momento inicial, os dois conversam sobre os motivos que fizeram com que André fugisse. A conversa é acompanhada por muito vinho, o que faz com que os dois falem tudo que estava preso por bastante tempo, devido à relação reprimida entre os membros da família. Nesse ponto, o filme explora outro elemento plástico-visual, a técnica do Chiaroscuro, que foi inventada na Europa renascentista e consiste em explorar a luz e a sombra como elemento estruturante na construção da pintura. 0 Chiaroscuro define os objetos sem usar linhas, apenas o contraste entre a luz e a sombra, de modo que a passagem da luz pelo espaço é o que dá perspectiva à pintura. Além disso, essa técnica nos traz uma espécie de texturização da imagem, dos objetos, que se tornam extremamente sinestésicos, como se pudéssemos sentir a imagem, como se os sentimentos expressos pelos personagens ganhassem textura, tornando-se quase palpáveis. Na versão fílmica, não percebemos onde a luz começa e onde termina, já que o efeito é difuso.

A técnica do Chiaroscuro se relaciona diretamente com a expressão dos sentimentos do personagem pelo uso, conforme já afirmamos, da subjetiva livre indireta, na qual a câmera e todo o 
processo fílmico acompanham, no caso em questão, a narração direta do personagem André. Assim, o efeito distorcido da cena pela iluminação também representa o estado de embriaguez dos personagens, da confusão de emoções e da incerteza do que traria aquele encontro, questões relacionadas à subjetividade do personagem que se fazem sentir na tela, dando vazão a manipulações estéticas típicas do cinema de poesia.

Além disso, a distorção provocada pelo jogo de luz nos leva ao campo do imaginário, do sonho, do onírico, característica essa ligada diretamente ao uso da câmera subjetiva e à própria natureza do cinema, segundo Pasolini (1966). O cinema de poesia, por meio da subjetiva livre indireta, seria, portanto, "uma espécie de retorno às origens, até encontrar nos meios técnicos do cinema a original qualidade onírica, bárbara, irregular, agressiva e visionária" (PASOLINI, 1966, p.279) desse meio semiótico. Esse caráter onírico do cinema, plenamente explorado em Lavoura Arcaica, diz respeito ao uso de signos pré-gramaticais, típicos do sonho, do inconsciente, dos arquétipos e da memória. No caso específico de produções fílmicas poéticas, esse caráter "pré-gramatical" é preservado, ao contrário de filmes "de prosa", em que a racionalidade é buscada, ainda que não seja plenamente alcançada devido à natureza do cinema.

Além de estética, o Chiaroscuro foi usado com o objetivo de representar a subjetividade, o sentimento de dualidade de André em relação à sua família e em relação a ele próprio. Isso porque, ao longo da história, no livro, André atribui a si mesmo características relacionadas ao escuro, ao sombrio, como quando diz "[...] e foi talvez, na minha escuridão, um instante de lucidez" (NASSAR, 1975, p. 25), enquanto sua família e o ambiente no qual ela vive está sempre relacionado à luz, à claridade e à luminosidade, "era boa a luz doméstica da nossa infância [...] essa claridade luminosa da nossa casa e que parecia sempre mais clara" (NASSAR. 1975, p. 27). Por vezes essa luminosidade torna-se excessiva, sufocando $o$ personagem, assim como fazia o convívio com sua família. 
A luz também costuma representar racionalidade, característica muito presente no pai, por exemplo. Enquanto André, em contrapartida, é totalmente passional, se deixando levar sempre pelas emoções, fato relacionado também às cores quentes predominantes no filme, conforme já abordamos.

Esse processo de ressignificar a luz e a sombra é extremamente metafórico. De início, a luz é apenas luz, entretanto ela ganha significados diferentes, que transcendem o caráter plástico-visual. Assim, a luz é usada como elemento visual buscando representar o que no livro é estrutural. São os procedimentos fílmicos que dão a entender a dualidade de André, ou seja, suas questões existenciais, dessa feita, o que no livro é narrado explicitamente, no cinema é sugerido pelos elementos formais comuns a essa arte.

Portanto, quando Pedro, o irmão mais velho, encontra André, o irmão perdido, no quarto de uma pensão barata, está em cena tanto a luz da família quanto a escuridão do irmão "perdido" no mundo. Dessa forma, o efeito sinestésico que é construído a partir do jogo de luz e sombra nos dá uma maior dimensão da metáfora que está sendo posta em cena. Ou seja, no filme, o espectador sente a cena e imerge-se nas imagens que são construídas, assim, o sentido é maximizado pela sua expressividade sinestésica, ao mesmo tempo em que somos arrebatados pelo seu caráter estésico.

Outro fator extremamente sinestésico e metafórico, características típicas da própria linguagem poética, é a forma como André adjetiva as frutas de forma sexualizada, em que signos usados comumente ganham significados que subvertem seu caráter original, levando-os ao nível poético ao ultrapassar o "nível" da linguagem comum. Segundo Paz (1982), esse caráter de elevação do nível da linguagem é característica comum à poeticidade.

Como dissemos acima, as frutas são sinestésicas e metafóricas. A sinestésia é perceptível dado que, ao longo da história, o personagem, inúmeras vezes, texturiza as frutas e salienta a sensação que elas produzem nele. Isso porque, geralmente, no livro, 
são apresentadas sensações relacionadas ao contato humano e ao tato, como, por exemplo, a maciez, a aspereza, a suavidade, a lisura, mas também sensações relacionadas ao molhado ou ao seco, à textura firme ou mole:

[...] e senti também, pensando nela, que estava por romper-se o fruto que crescia em minha garganta, e não era um fruto qualquer, era um figo pingando em grossas gotas o mel que me entupia os pulmões e já me subia soberbamente aos olhos, mas num esforço maior, abaixando as pálpebras, fechei todos os meus poros. (NASSAR, 1975, p. 39).

Nesse trecho, além da sinestesia, percebemos o processo de metaforização das frutas, de modo que a descrição que André faz da sensação que teve ao lembrar da mãe é extremamente sexual. O figo pingando em grossas gotas de mel remete, por exemplo, ao sêmen, que vem logo após a sensação do fruto se romper, ou seja, do ápice do prazer sexual, da própria ejaculação. Outro ponto a se pensar é a adjetivação do sêmen como mel, que é mencionado na tradição religiosa como fonte de vida, de cura e de prazer, esse último por conta de sua doçura.

Todas essas sensações de contato humano simbolizado pelas frutas, produzidas a partir da visão de André, se constroem em torno de duas figuras que, na história, estão relacionadas com o personagem no aspecto sentimental e no sexual. Essas figuras são a sua mãe e a sua irmã, Ana. As duas personagens representam também a própria vida, principalmente a mãe de André, já que é à figura da mãe que sempre se atribui a ideia daquela que dá a luz, que traz à vida e que a mantém.

Além disso, é interessante pensar que o fruto está relacionado na cultura geral à própria ideia de vida, de algo que nasce, cresce, alimenta e, também, reproduz, já que, no caso, o fruto está relacionado à ideia de sexo e, consequentemente, de reprodução. Outra interpretação para o fruto é o pecado, a proibição, aquilo que é tentador e fonte de desejo. Ora, a mãe de André Ihe deu a vida, 
o alimentou, não só a ele, mas também a toda a família, portanto ela era o fruto, cheia de vida, acolhedora, afetuosa, a provedora. Ana, por outro lado, era a tentação, o fruto proibido do desejo e do pecado. Ambas são, para André, uma confusão de desejos reprimidos simbolizados nas frutas e na ideia de um fruto.

As frutas são, então, vistas como um objeto de desejo metaforizado, no qual André vê a figura de sua irmã, que é a fonte do seu desejo. Por outro lado, o fruto é o resultado de um processo de construção de um símbolo, dentro da narrativa. Dessa forma, a ideia do fruto é mais que apenas algo comestível, na verdade não chega nem a ser algo concreto, o fruto é uma ideia, a qual conjuga todos os desejos e frustrações do personagem, mas também é o resultado de toda a sublimação da percepção do personagem sobre os elementos que o rodeiam. Essa ideia do fruto passa por um processo de construção formal na qual o autor maximiza os significados dos signos, tornando-os poéticos.

No filme, a expressividade da relação das frutas com o desejo de André se encontra principalmente na forma como as cenas são filmadas, pois o toque é explorado de inúmeras formas, sendo que o tato e as sensações provenientes dele são apresentadas por enquadramentos muito próximos das mãos das personagens, revelando os mínimos detalhes de sua pele, quando estas tocam alguma coisa. Como exemplo, podemos citar quando as mãos de André encontram as mãos de sua mãe por baixo do lençol e a câmera acompanha o toque dos dois, maximizando as sensações daquela cena. Esse jogo de cena é o que se chama de "fazer sentir a câmera", uma característica comum ao cinema de poesia. $\mathrm{Na}$ cena em questão, sentimos a câmera por meio da gravação em primeiríssimo plano, no qual temos a visão apenas de um objeto, "descolado" do contexto: as mãos, que simbolizam a união, o contato puro e, indiretamente, o sexo.

Outro aspecto poético que pode ser observado, em ambas as obras, livro e filme, é o misto de sensações opostas e também relacionados com os sentidos narrados por André quando ele, não só para fugir da família, mas também para expurgar seus desejos, 
deita-se embaixo das árvores, cobre-se de folhas e enfia os pés na terra. $O$ trecho seguinte exemplifica essa situação altamente sinestésica:

[...] amainava a febre dos meus pés na terra úmida, cobria meu corpo de folhas e, deitado à sombra, eu dormia [...] meu sono, quando maduro, seria colhido com a volúpia religiosa com que se colhia um pomo. (NASSAR, 1975, p. 13).

Podemos perceber o contraste entre o calor do seu corpo inundado de desejo em contraposição à umidade e à frieza acolhedora da terra, da qual ele passa a fazer parte. Nesses momentos, nos quais o personagem se encontrava em fuga do mundo exterior, em que dormia no tronco da árvore, o seu sono era visto como a experiência máxima de concretização do desejo, como podemos perceber na seguinte parte da citação "[...] meu sono, quando maduro, seria colhido com a volúpia religiosa com que se colhia um pomo" (NASSAR, 1975, p. 13).

Nesse trecho podemos perceber que André está se referido ao acontecimento como uma transcendência religiosa e sexual, já que o sono não é apenas sono, e sim uma experiência de prazer. O que acontece é um misto de prazer por meio dos sentidos, de modo que há uma transcendência, confluindo num misto de sensações. É um momento de transcendência pelo prazer sobre-humano no qual André, por meio do sono, sai da realidade objetiva e ascende a outros níveis de existência.

No filme, somos apresentados à imagem de André coberto por folhas secas, com os pés enfiados na terra. A paleta de cores na cena é predominantemente quente, e o corpo do personagem é apresentado fragmentado pela câmera em close, ora focando nos seus olhos, ora nas folhas, ora nos seus pés se enterrando na areia, acompanhando todo o movimento realizado pelo personagem. A câmera em close, como já afirmamos, potencializa as sensações, pois revela nos mínimos detalhes as características daquilo que é focalizado. 
Ao longo da narrativa, nos deparamos com outros momentos de grande efeito sinestésico e metafórico que referem-se ao fruto, como quando André descreve para seu irmão Pedro como foi sua despedida de sua mãe, ao partir de casa. Na ocasião, ele diz:

[...] mas tudo o que pude ouvir, sem que ela dissesse nada, foram as trincas da louça antiga do seu ventre, ouvi dos seus olhos um dilacerado grito de mãe no parto, senti seu fruto secando com meu hálito quente. (NASSAR, 1975, p. 68).

Esse trecho foi construído a partir de metáforas e da oposição das sensações exploradas pelo narrador. Primeiro, o narrador continua desenvolvendo a ideia do fruto, como já citado anteriormente. Nesse caso, o fruto que André sente secar também remete à ideia de vida, que está sempre relacionado com o molhado ou úmido. Logo após, a comparação entre ventre e louça antiga remete a algo delicado, mas, sobretudo, de esquecimento, principalmente quando a louça antiga possui trincas, rachaduras. É a louça que porta o alimento, a vida, quando em uso, mas que é abandonada, envelhecida, quando já não possui mais esse alimento.

Ainda nesse trecho, o narrador afirma ouvir, no silêncio da mãe, o grito da dor do parto, sendo possível entender que o sentimento de perda é comparado ao de ganho, já que no parto o filho é dado a mãe, no momento da partida, este lhe é tirado. A vida de sua mãe acaba, perde o sentido, no momento da partida do filho. A expressividade desse momento é elevada pelo uso de antíteses, outra figura de linguagem associada à linguagem poética, entre o molhado e o seco, quente e frio, entre o grito e o silêncio, entre o novo e o velho. Essa oposição traz certo ritmo à narração por causa da repetição contínua dessas características, sendo que o elemento rítmico é típico da prosa poética.

No filme, esse momento da partida de André é apresentado por uma única imagem da mãe de André na janela, por trás do vidro, as mãos em direção ao filho, o semblante de dor e, mais que tudo, silêncio. Todo o sentimento da cena é explorado pela ausên- 
cia de som ou qualquer ação mais drástica da mãe em relação à partida do filho. A cena é enquadrada como uma pintura, imóvel, imortalizando aquela dor, aquele momento, isto é, a partida do filho mais amado, o começo da ausência de vida na mãe.

É interessante pensar que tanto no livro como no filme a mãe de André não recebe um nome, nem mesmo seu pai. Os dois são vistos como figuras imutáveis e que representam papeis sociais muito bem definidos, sendo, portanto, arquétipos. Os irmãos, por outro lado, possuíam nomes e características que os distinguem, apesar de nem todos possuírem características destoantes dos papéis sociais para eles definidos.

A recusa dos papéis arquetípicos por parte de alguns filhos coloca esses personagens longe do aspecto do que é esperado pelos pais, encerrando a linearidade e a circularidade dos papéis sociais. Também significa uma quebra no modus vivendi da família tipicamente patriarcal, ou seja, do mecanismo que a põe nos "eixos". Essa ideia patriarcal remete à figura do avô, por exemplo, que representa a secularidade dos padrões que a família deveria seguir. Também remete ao próprio modo cíclico como a família vivia, como numa lavoura, com ações repetidas e rotineiras, todos com uma função, buscando apenas a sobrevivência.

A ruptura do modus vivendi cíclico da família coincide, tanto na literatura quanto no cinema, com o ponto máximo de metaforização e da corporificação dos sentidos nas obras, no desfecho de ambas, quando Ana dança na festa de comemoração pela volta de André. Nessa ocasião, vestida com os objetos das prostitutas que André colecionava, Ana já não tem a mesma presença das outras aparições, nas quais dançava com seu irmão mais velho. Pelo contrário: ela assume a postura do arquétipo das mulheres de quem André ganhou os objetos. Além disso, reclusa desde a partida do irmão, quando este retorna a casa, todo o seu sentimento reprimido vem à tona, levando Ana a expurgar, com o corpo, por meio da dança, os sentimentos pelo irmão, da mesma forma como André fazia com as folhas e a terra úmida. Assim, Ana entra na dança: 
impaciente numa lufada só, os cabelos soltos espalhando lavas [...] toda ela ostentando um deboche exuberante [...] varando com a peste no corpo o círculo que dançava, introduzindo com segurança, ali no centro, a petulante decadência. (NASSAR, 1975, p. 188).

Nesse trecho, podemos perceber o processo de construção poética quando André descreve o movimento dos cabelos de Ana comparando-os a lavas se espalhando, aumentando a sensação de movimento, dinamicidade, de calor e de morte. Ana, mais uma vez, se torna o centro de tudo. Dessa vez, literalmente, por que ela não domina apenas os sentimentos e a atenção de André, mas também de todos da família, ditando o ritmo da dança, da música, e até do próprio movimento da natureza, o que nos leva outra vez à questão do ritmo, proposta por Paz (1982). No filme, o ritmo da cena é composto pelo movimento em uníssono entre a dança de Ana, a trilha sonora, a dança das pessoas ao seu redor e também dos movimentos da câmera.

Na sequência, tanto na literatura como no cinema, Ana começa a derramar vinho pelo corpo enquanto dança, e é nesse ponto que tanto a metaforização quanto a confluência de sensações atingem seu ápice. O vinho é alimento litúrgico, sagrado, ou seja, assim como o sexo, leva à transcendência. Enquanto o primeiro por causa do caráter religioso, o segundo pelo prazer. Liturgicamente, o vinho tem grande importância nas religiões, sendo atribuído a ele a transmutação do sangue de Cristo e, justamente por isso, o caráter de bebida sagrada. Além disso, o vinho também era a bebida do deus Baco, conhecido por ser também o protetor da fertilidade. As festas para a adoração a ele eram regadas a muito vinho e erotismo. Nesse caso, o vinho possui simultaneamente caráter sagrado e profano, assim como Ana, a filha recatada e também indecente.

O vinho também é estímulo por meio da visão, porque enfatiza, em conjunto com os objetos das prostitutas, os movimentos de Ana, causando um delírio visual. Além de relacionado ao paladar, 
Ìndices de poesia em lavoura arcaica: da literatura ao cinema

Francisco Heitor Pimenta Patrício • Ana Carolina Negrão Berlini de Andrade

o vinho com que Ana embebe a sua carne é tátil, porque escorre por seu corpo, marcando suas formas. Percebemos essa mistura de sensações no livro pela seguinte passagem:

\begin{abstract}
essa minha irmã, sabia molhar a sua dança, embeber a sua carne, castigar a minha língua no mel litúrgico daquele favo, me atirando sem piedade numa insólita embriaguez [...] e nessa postura aparentemente descontraída fiquei imaginando de longe a pele fresca do seu rosto cheirando a alfazema, a boca um doce gomo, cheia de meiguice, e os meus olhares não se continham, eu desamarrei os meus sapatos, tirei as meias e com os pés brancos e limpos fui afastando as folhas secas e alcançando abaixo delas a camada de expresso húmus. (NASSAR, 1975, p. 190-191).
\end{abstract}

Assim, de longe André assiste aquela dança e consegue sentir seu cheiro (olfato) e também a textura (tato) de sua pele, que outra vez remete à maciez e a outras texturas que ele atribui às frutas. Dessa forma, o personagem mistura a sensação de frescor com a maciez e com o olfato para descrever a pele de Ana, que ele, mesmo distante, pode sentir, devido aos estímulos sensoriais. De maneira análoga ao que acontece com o personagem, as descrições metafóricas e sinestésicas suscitam sensações no leitor/ espectador.

Dessa forma, quando Ana molha sua carne e a embebe com vinho, ela está sacralizando o seu corpo, abençoando-o. A cena, na verdade, assume um caráter ritualístico com o movimento das pessoas ao redor de Ana, como se estivem reverenciando-a, adorando. O sangue de cristo escorre pelo corpo da personagem levando-a ao êxtase, entretanto, o êxtase ao qual ela chega não é apenas religioso, pois sobre o seu corpo também cai a bebida do deus da fertilidade, das orgias, do pecado.

André, nesse momento, é levado a um nível extremo de prazer, confundindo a realidade com o onírico, podendo sentir de longe a sensação do corpo de Ana. Assim, traz outra vez a ideia do fruto 
doce e suculento em sua boca, que representa o seu desejo. Dessa forma, o caráter simbólico da cena e a convergência de sensações ampliam o efeito sinestésico da obra, além de criar toda uma imagem da transcendência a qual os personagens experimentam.

No filme, somos apresentados a essa cena por meio de uma câmera única que acompanha em close todos os movimentos de Ana, acompanhando o vinho escorrendo pelo seu corpo, combinando com a cor do seu batom e da flor que leva no cabelo. A expressão de Ana é, acima de tudo, de prazer. O efeito de prazer e êxtase acomete não só André, mas também Ana. O deleite ao qual ela se entrega aumenta não só a expressividade sinestésica e poética da cena, como simula a percepção de André, que permanece imóvel assistindo a tudo.

A música, no filme, que até o momento era feita pela melodia tocada pelas pessoas em roda em volta de Ana, vai diminuindo na medida em que a personagem dança e seu êxtase aumenta. Gradativamente, os sons externos vão sumindo, e surge uma melodia instrumental lenta, porém intensa, que vai aumentando conforme a personagem dança. A ausência de sons diegéticos representa a transcendência de Ana, pelo prazer da dança e pela simbologia sexual que a cena expressa, assim como o ritmo que vai ganhando intensidade até o ápice da cena, a morte de Ana.

Nesse ponto da história, Pedro, o irmão mais velho, conta a seu pai o que aconteceu entre Ana e André, e este, tomado pela ira, se dirige ao grupo de dança e mata a filha. Entretanto, Ana não morre, necessariamente, em consequência do ato sexual, mas sim por estar dando vazão ao seu prazer, já que, na simbologia religiosa, o corpo é o caminho para o pecado, e é a partir dele que chega-se ao sexual, à materialização do mal. Outro ponto é que, ainda na tradição religiosa, uma mulher expressar seus desejos, vontades e prazeres carnais é ainda mais inaceitável. Portanto, a morte de Ana é vista tanto como um ato de redenção dos seus pecados, como também de salvação da família.

O tom sexual que a cena até o momento tinha construído se desfaz no caos que começa a ser construído com a descrição, no li- 
vro, da agonia sentida pelo irmão Pedro e pelo seu pai no momento em que eles descobrem o caso entre Ana e André: "[...] a flauta desvairava freneticamente, a serpente desvairava no próprio ventre, e eu de pé vi meu irmão tresloucado ainda ao descobrir o pai, disparando até ele, agarrando-lhe o braço" (NASSAR, 1975, p. 192).

Nesse ponto, enquanto o desespero do irmão e do pai é narrado no livro por meio da pressa e do descompasso do fluxo de consciência de André, no filme, a cena é filmada de baixo para cima, a cor do céu é estourada e só conseguimos ver a luz, tornando a iluminação da cena excessiva. Esse recurso estético-visual desempenha papel poético, pois representa, no momento, o estado de confusão mental na qual o personagem se encontra, como também de ofuscamento dos sentidos.

A luz muda na ocasião em que Pedro encontra o pai, pois, nesse momento, a iluminação fica mais escura, de modo que não conseguimos enxergar as expressões faciais dos dois, apenas suas sombras em contraste com a luz exterior. As cenas começam a ser apresentadas fragmentadas e em câmera lenta, não existindo uma organização lógica dos fatos. Primeiro, a câmera foca na arma, em plano fechado, logo após no desespero da mãe tentando controlar a filha, em seguida o pai aparece segurando a arma em direção a Ana, e então a câmera foca em seu pescoço. A rosa vermelha que Ana trazia nos cabelos cai no chão, despedaçada, e o caos se instala.

Nesse ponto, as imagens outra vez são distorcidas, os rostos dos personagens filmados em plano detalhe ou fechado, aumentando a atmosfera de desespero da cena, pois enfatiza as expressões dos atores e sugere confusão mental, desordem e perturbação. Os acontecimentos, como acabamos de ver, não são explícitos. O que temos nesse ponto do filme são sugestões, justamente porque o foco não está na história contada, mas nos procedimentos fílmicos, que no caso, sugerem o significado. A montagem deslocada, com o uso da subjetiva livre indireta, segundo Pasolini (1966), não é linguística, e sim estilística. Ela age como articuladora da li- 
berdade de expressão da cena, levando-a ao caráter "onírico, bárbaro, irregular e agressivo" (PASOLINI, 1966, p. 279).

Nesse trecho da morte da personagem Ana, esse recurso poético é vastamente explorado, dando a impressão de caos e de desespero que o momento traz, fazendo com que o espectador sinta que as emoções ali representadas não cabem na realidade objetiva, levando-o a sensações que vão da confusão mental até a concretude dos sentimentos da cena. Entretanto, momentos antes da morte de Ana, esse mesmo recurso foi utilizado não para representar o caos, mas a poeticidade do desejo sexual, como quando a câmera focava insistentemente nos pés de André afundando na areia enquanto este acompanha os movimentos da dança de Ana junto com montagem desordenada e não linear.

Ainda na cena do clímax da morte de Ana, o foco da câmera na rosa vermelha despedaçada é extremamente simbólico. À rosa vermelha dá-se o significado de ápice da paixão, do sangue e da carne. São esses três pontos que convergem em toda a cena: as paixões da família que foram excessivamente reprimidas, o sangue lavando o pecado, a carne como símbolo do desejo, do pecado, gênesis de todo o mal.

Logo após, o livro e o filme se encerram de formas distintas, mas se complementam. Dessa forma, no filme, surge a imagem de André, deitado, coberto pelas folhas, a câmera focando os seus olhos e o céu. Pouco a pouco a imagem vai se desfocando e a tela escurece. A música ao fundo é uma versão mais calma e menos intensa da que é tocada durante o ápice da cena, um quase silêncio dando a impressão de paz. Por outro lado, o livro termina com uma frase relacionada à mãe de André, que diz: "[...] puxando um lamento milenar que corre ainda hoje a costa do pobre mediterrâneo: tinha cal, tinha sal, tinha naquele verbo áspero a dor arenosa do deserto" (NASSAR, 1975, p. 194).

A aproximação do livro com o filme aqui é feita com relação ao tempo, que não para, ele é fluido, irreversível, e permeia toda a narrativa, assim como também é circular, e se confunde com 
Ìndices de poesia em lavoura arcaica: da literatura ao cinema

o lamento milenar da mãe que chora a perda, confluindo com a imagem das folhas e do sol ainda de forma desfocada, e as árvores num movimento ritmado, assim como o tempo. A câmera subjetiva usada aqui tem como objetivo justamente sugerir o olhar do personagem percebendo o ritmo da natureza e do tempo que o circunda.

\section{Considerações Finais}

Levando-se em conta o que foi exposto, podemos perceber que existe entre a literatura e o cinema uma diferença fundamental e intransponível, já que possuem sistemas semióticos diferentes. Logo, cada obra possui sistemas distintos de mimetizar a realidade objetiva. Entendendo-se esse fato, o caminho para encontrar meios de aproximação entre duas obras de sistemas semióticos distintos, como a literatura e o cinema, e o modo como compreendemos o processo de adaptação torna-se mais coerente. Assim, não nos atemos à similaridade "pura" entre as obras, mas aos processos a partir dos quais o livro e o filme foram construídos estética e formalmente, sugerindo uma possibilidade de diálogo estrutural.

Desta feita, percebeu-se que a aproximação entre as duas obras analisadas se fez por meio da presença da poesia, a qual não ocorre apenas no plano conteudístico, mas também na estrutura. Assim, seguindo as características atribuídas por Paz (1982) ao que é poético, analisamos as duas obras, relacionando também à noção de poesia no cinema, proposta por Pasolini (2000).

Dessa maneira, foi possível perceber que, no caso do livro, a escrita ritmada e as constantes metáforas suscitavam significados para além da realidade referencial. Dessa forma, o discurso e a narração estão em esferas ideológicas diferentes, porque assim como acontece na poesia propriamente dita, na escrita com qualidades poéticas temos um menor nível de referência à realidade 
objetiva, assim, somos lançados ao devaneio, vivemos no onírico, acompanhando a narrativa sob a visão do personagem, do eu-lírico.

No caso do filme, a poeticidade estrutural é construída a partir do uso da câmera, principalmente, de forma a subverter as regras do cinema convencional, dando à narrativa fílmica um atestado de subjetividade, incerteza, e no qual nada é objetivo, pelo contrário, tudo é sugerido. Isso nos dá a impressão de estarmos, assim como acontece na narrativa do livro, vivendo a história do personagem, pois o que acontece não é mediado por uma câmera invisível, mas sim pela sua psiquê.

Outro ponto de intersecção para o processo de adaptação é a maneira como o caráter sexual, característica do livro, ganha forma no filme por meio do processo de metaforização dos signos. Portanto, assim como no livro, o que temos é a hiper sexualização de signos comuns, de modo que, quando subvertidos, aumentam a expressividade, porque revelam novos significados. Um exemplo disso, conforme abordamos na análise, é a caracterização excessiva das frutas e a comparação com a mãe e com a irmã, na qual convergem não apenas o aspecto sexual, mas também o religioso. Inclusive, é o aspecto religioso um dos mais metaforizados, de modo que a transcendência religiosa e a sexual se tornam uma só.

Os aspectos desenvolvidos anteriormente são construídos também com intuito de reforçar o caráter sinestésico das obras. Dessa forma, as construções metafóricas muitas vezes remetem às sensações, e o caráter sexual é permeado por apelos sensoriais. Essa presença do misto de sensações tornam as obras expressivas e, consequentemente, mais poéticas. Assim, estabelece-se gradativamente uma relação entre o poético, as sensações e o sexual. O desejo, o aspecto sexual, carnal e espiritual, é explorado poeticamente tanto na estrutura do filme e do livro quanto nas suas temáticas.justamente porque o foco não está na história contada, Percebe-se que o sentido é polissêmico, ou seja, tudo é possível a interpretações e, na maioria das vezes, culmina no sexual, explorado pelos sentidos. 
Ìndices de poesia em lavoura arcaica: da literatura ao cinema

Francisco Heitor Pimenta Patrício • Ana Carolina Negrão Berlini de Andrade

Dessa forma, o filme, ao se propor a realizar uma adaptação do livro, cumpre seu papel, mantendo suas características próprias, não visando ser igual ao livro, mas buscando suscitar no espectador os significados e imagens similares às que o livro suscita no leitor.

\section{Referências}

ANDRADE, Ana Carolina Negrão Berlini de. Trans-formações (a)temporais em II Decameron: de Pasolini a Boccaccio. 2010. 226. Dissertação (Mestrado em Teoria da Literatura) - Instituto de Biociências, Letras e Ciências Exatas, Universidade Estadual Paulista, São José do Rio Preto, 2010.

BRITO, João batista de. Literatura no cinema. São Paulo: Unimarco, 2006.

BOSI, Alfredo. $O$ ser e o tempo da poesia. São Paulo: Cultrix, 1977.

EISENSTEIN, Sergei. O Sentido do filme; apresentação, notas revisão temática. Rio de Janeiro: Jorge Zahar, 2002.

CUNHA, R. Cinematizações. Brasília: Círculo de Brasília Editora, 2007.

JAKOBSON, R. Lingüística e poética. In: JAKOBSON, R. Lingüística e comunicação. São Paulo: Cultrix, 2010, p. 150-207.

LAVOURA arcaica. Direção: Luiz Fernando Carvalho. Produção: Glauber Rocha. Europa Filmes, 2001. Disponível em: https://www.youtube.com/ watch?v=FnibQvMlq-I. Acesso em: 31 jan. 2019.

NASSAR, Raduan. Lavoura arcaica. São Paulo: Companhia das Letras, 1989.

PAZ, Octávio. 0 arco e a lira. Rio de Janeiro: Nova Fronteira, 1982.

PASOLINI, Pier Paolo. A poesia do novo cinema. Revista Civilização Brasileira, Rio de Janeiro, n.7, p. 267-287, 1966.

PASOLINI, Pier Paolo. Empirismo eretico. Milano: Garazanti, 2000. 
Ìndices de poesia em lavoura arcaica: da literatura ao cinema

Francisco Heitor Pimenta Patrício • Ana Carolina Negrão Berlini de Andrade

SARAIVA, Juracy Assman. Literatura e Cinema: encontros e linguagens. In: SARAIVA, Juracy Assman. Narrativas verbais e visuais: leituras refletidas. Rio Grande do Sul; Editora Unisinos, 2003, p. 9-26.

SAVERNINI, Erika. Índices de um cinema de poesia: Pier Paolo Pasolini, Luis Buñuel e Krzysztof Kieslowski. Belo Horizonte: Editora UFMG, 2004. 